\title{
PCR DETECTION OF PATHOGENIC BACTERIA IN MILK AND SOFT CHEESE UNDER DIFFERENT COW'S PRODUCTION SYSTEMS IN MEXICO
}

\author{
Ameer E. ELFARASH ${ }^{a,{ }^{*}}$, Francisco J. SOLORIO-SÁNCHEZ ${ }^{\text {b }}$, Rafael A. ROJAS-HERRERA ${ }^{c}$, Victor M. TOLEDO- \\ LOPEZ ${ }^{\text {d, }}$ and Yaser M. A. EL-DERWY b,e \\ a Department of Genetics, Faculty of Agriculture, Assiut University, Assiut (71526), Egypt. \\ b Faculty of Veterinary Medicine and Animal Science (CCBA), Autonomous University of Yucatan (UADY), \\ Merida, Yucatan (97100), Mexico. \\ c Faculty of Chemical Engineering, Autonomous University of Yucatan (UADY), Merida, Yucatan (97203), \\ Mexico. \\ d Merida Institute of Technology, Merida, Yucatan (97118.), Mexico. \\ e Department of Dairy science, Faculty of Agriculture, Assiut University, Assiut (71526), Egypt.
}

*Corresponding author: Ameer E. ELFARASH

Department of Genetics, Faculty of Agriculture, Assiut University, Assiut (71526), Egypt.

Tel: (+2) 01005392548 E-mail: aelfarash@aun.edu.eg

\begin{abstract}
Thirty six samples of raw milk were collected from three different farms located in Merida, Yucatan, Mexico and seventy two samples of soft cheese were manufactured from thirty six samples of raw milk and thirty six samples of pasteurized milk from the previous collected raw milk during May 2013 to April 2014. The first and second farm located at Faculty of Veterinary Medicine and Animal Science, Autonomous University of Yucatan (FMVZ/UADY) used two different production regimes; intensive silvopastoral system (ISS) and traditional system (TS). The third farm in Kampepen under (ISS). The collected raw milk samples were divided into three portions, one portion of raw milk and two portions for soft cheese manufacture from (raw and pasteurized milk) for PCR screening. PCR screening was performed for one hundred and eight samples to detect four types of the most dangerous foodborne pathogens (Escherichia coli 0157:H7, Salmonella enterica serovar Typhimurium, Staphylococcus aureus and Listeria monocytogenes). PCR results showed that almost samples were negative for all tested pathogens except six samples (5.56\%); 3 samples of raw milk and other 3 samples of soft cheese manufactured from this raw milk under traditional system which were positive for Staphylococcus aureus.
\end{abstract}

Key words: PCR, Pathogenic bacteria, Raw milk, Soft cheese, Production systems.

\section{INTRODUCTION}

Cheese is the generic name for a group of fermented milk-based food products. There are more than 1,000 varieties of cheese (Fox et al. 2004). Most of the Mexican cheeses are soft cheese and made locally from raw milk (Olson et al. 2011; Renye et al. 2011; Aldrete-Tapia et al. 2014; Gould et al. 2014; Pereira-Suarez et al. 2014). The quality and safety of the cheese depends on raw milk contamination by microorganisms, efficiency of processing and the hygienic practice applied in dairy farms and dairy factors, transportation from dairy farms to dairy factors, handling and manipulation of milk during

Special volume for the first International Conference of Genetic Engineering and Biotechnology, Sharm el Shiekh, Egypt. 26-29 April, 2016 
manufacture. All together can impair its utility and renders the product unsafe for human consumption (Leuschner and Boughtflower 2002). Due to the high microbial contamination present in raw milk, pasteurization is commonly used to eliminate all pathogenic and most of nonpathogenic organisms before its further processing into cheese (Silvestre et al. 2008; Elizondo-Salazar et al. 2010; Silva et al. 2010; Morales-Celaya et al. 2012; Van Gysel et al. 2012).

In Mexico, consumers prefer soft cheese manufactured from cow's raw milk due to the presence of microorganisms which enhances the flavor of the soft cheese, but this raised the concern about the safety of the cheese (SolanoLópez and Hernández-Sánchez 2000; MoralesCelaya et al. 2012). There are no enough data on cheese contaminated with species, especially; Escherichia coli 0157:H7, Salmonella enterica serovar Typhimurium, Staphylococcus aureus and Listeria monocytogenes present in Mexican and American markets (Torres-Llanez et al. 2006; Omiccioli et al. 2009). These pathogens are the most dangerous foodborne bacterial in terms of human health and disease, and their detection through current microbiological analyses methods involves considerable spending of time and effort (Omiccioli et al. 2009). Pathogenic bacteria can produce numerous toxins and leading cause of gastroenteritis and vomiting resulting from consumption of contaminated dairy product (Nedelkov 2000; U.S. FDA 2001). Contaminated milk and soft cheese with pathogenic bacteria often are involved in outbreaks (Bergdoll 1997).

PCR is a rapid and sensitive diagnostic method for detecting pathogenic bacteria. Therefore, it was used for detecting the pathogenic bacteria in this research according to (Holland et al. 2000; Gouws and Liedemann 2005; Omiccioli et al. 2009; Wu et al. 2012).

In Mexico, intensive silvopastoral systems based on tropical grasses and Leucaena leucocephala are gradually expanding in the feeding of milking cows. Incorporation of tree legumes such as Leucaena leucocephala in silvopastoral systems represents an alternative in tropical ruminant production as it plays an important role in providing a forage rich in nutrients, especially protein, vitamins, and minerals (Barros-Rodríguez et al. 2012).

In this study, we focused on PCR detection of four types of pathogens (Escherichia coli 0157:H7, Salmonella enterica serovar Typhimurium, Staphylococcus aureus and Listeria monocytogenes) present in raw milk and soft cheese manufactured from raw and pasteurized milk under intensive silvopastoral and traditional systems in Yucatan, Mexico. The ultimate goal of this study was to help dairy industry to produce healthy and safe milk as well as soft cheese to the consumers in Mexico. Also, appropriate action can be taken to minimize healthy risk.

\section{MATERIALS AND METHODS}

\section{Milk samples:}

Three raw milk samples (11 L/sample) were collected monthly in a total of thirty six samples from three different farms located in Merida, Yucatan, Mexico during May 2013 to April 2014. The milking cows of the first and second farm located at Faculty of Veterinary Medicine and Animal Science, Autonomous University of Yucatan (FMVZ/UADY) were reared under two different production regimes; intensive silvopastoral system (ISS) and traditional system (TS). The milking cows of the third farm in Kampepen, Merida, Yucatan, Mexico were reared under intensive silvopastoral system (ISS). The differences in the nutrient ingredients between production systems are shown in (Table 1 ).

A bulk of fifteen milking cows from each production system was used for getting raw milk samples. 
Table 1. The nutrient ingredients of the experimental production systems during May 2013 to April 2014 in Merida, Yucatan, Mexico.

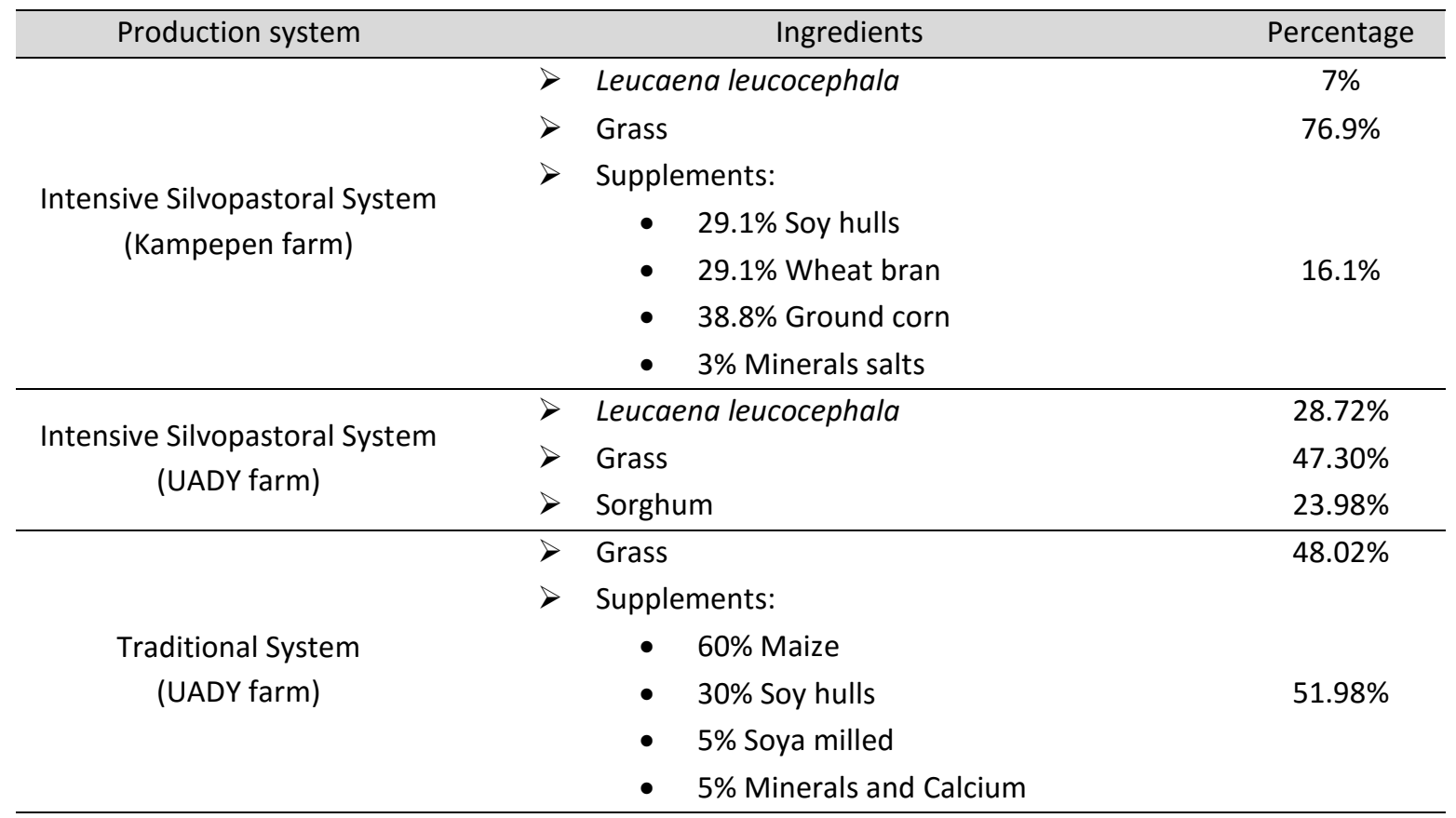

\section{Production systems:}

In the first and second farms (FMVZ/UADY), 24 multiparous ( $\geq 3$ calves) Bos indicus $x$ Bos taurus cows (Holstein and Brown Swiss $x$ Zebu were used; with proportion of European genes ranging from $50-75 \%)$ at calving. The mean body weight of the cows was $509 \pm 74 \mathrm{~kg}$ (mean \pm SD) with a body condition score $(\mathrm{BC})$ of $6 \pm 0.3$ points. All the cows were familiarized to the consumption of Leucaena forage as part of the routine diet. The cows were divided in two homogenous groups according to the previous milk yield and calving interval, and were allocated at calving to the following treatments: (ISS) ( $n=12)$, a Intensive Silvopastoral System, consisting of an association of stargrass and Leucaena (Cynodon nlemfuensis - Leucaena leucocephala); (TS) ( $n=12)$, a Traditional System (control) group where the cows grazed in a monoculture of stargrass. The grazing area was 4.3 hectare for (ISS) and 3.0 ha for (TS), with stocking rates of $2.4 \mathrm{AU} /$ hectare (1 animal unit
$[\mathrm{AU}]=450 \mathrm{~kg}$ live weight) and $2 \mathrm{AU} / \mathrm{ha}$ for (ISS) and (TS), respectively. The stocking rates were fixed based on previous works for (ISS) (Mayo 2013) and (TS) taking into account the forage availability. To keep the stocking rate in both treatments during the experiment, there were incorporated external animals as necessary, using the "put and take" method. Both groups of cows were grazed from (5:00 pm to 5:00 am) and from (8:00 am to 1:00 $\mathrm{pm})$. In order to avoid weight losses which could affect the response variables, all the cows were supplemented during the milking in the morning and evening (am and pm) to fulfill their protein and energy requirements for milk yield. Because of the composition of the forages, it was used ground sorghum as an energy supplement for (ISS) and a commercial concentrate to supply energy and protein for (TS) as shown in (Table 1). All the cows had access to a mineral mixture and water ad libitum. 
In the third farm (Kampepen), 24 multiparous ( $\geq 3$ calves) Bos indicus $x$ Bos taurus cows (Holstein $x$ Zebu were used; with proportion of European genes ranging from $50-75 \%$ ) at calving. The mean body weight of the cows was $537 \pm 53 \mathrm{~kg}$ (mean \pm SD) with a body condition score (BC) of $6 \pm 0.8$ points. All the cows were familiarized to the consumption of Leucaena forage as part of the routine diet. All the cows were reared under Intensive Silvopastoral System (ISS), consisting of an association of guinea grass and Leucaena (Pannicum maximum - Leucaena leucocephala). The grazing area was 7 hectare for (ISS) with stocking rates of $3.5 \mathrm{AU} /$ hectare (1 animal unit $[\mathrm{AU}]=450 \mathrm{~kg}$ live weight). The cows were milked dally at 8:00 am, all the cows were supplemented during the milking in the morning as shown in (Table 1). To keep the stocking rate in the summer and winter, during the experiment in the summer (3.5 $\mathrm{kg}$ dry matter additional citrus peel) to supplement the animals during the time of milking. The cows grazed from 12:00 pm to 8:00 am the next day.

\section{Cheese manufacture:}

Six soft cheese samples were manufactured monthly in a total of 72 samples from the previous collected milk. The soft cheeses in each one of the three production system were manufactured from raw and pasteurized milk in the dairy laboratory at (FMVZ/UADY).

One portion of raw milk ( $5 \mathrm{~L}$ ) was used for soft cheese manufacturing, while the other $(5 \mathrm{~L})$ was pasteurized to $73^{\circ} \mathrm{C}$ for $15 \mathrm{sec}$. followed by sudden cooling at $5^{\circ} \mathrm{C}$ then warmed to $40^{\circ} \mathrm{C}, 3 \%$ of salt was added to raw and pasteurized milk. $100 \mathrm{~L}$ of each milk was coagulated by adding $10-15 \mathrm{ml}$ of liquid rennet (Cuamix) in 30-40 min. After that, the curd was cut and the pieces of curd were powered into a fine cotton cloth in aluminum molds and pressed by light weight for 24 hours to excrete the whey.
Then, the obtained soft cheese were weighted to determine the percentage of yield.

\section{Microbial enrichment:}

To improve the sensitivity of detection by PCR, an enrichment step was done in the laboratory of Microbial genetics, department of genetics at the Faculty of Agriculture, Assiut University, Assiut, Egypt. Milk and soft cheese samples were added to an enrichment media and then incubated at $36 \pm 1^{\circ} \mathrm{C}$ for $24 \mathrm{~h}$ for the further investigation. To identify the pathogen, different enrichment media were used as follow: Trypticase Soy Broth (TSB) for Escherichia coli 0157:H7 (Lye et al. 2013); BairdParker Agar Base for Staphylococcus aureus (Rahimi and Alian 2013); Listeria Enrichment Broth Base for Listeria monocytogenes (Amagliani et al. 2006); and selenite brilliant green sulfa enrichment (SBG) broth for Salmonella enterica serovar Typhimurium (Chang et al. 1999).

\section{DNA extraction:}

DNA extraction by boiling method was carried out as previously described with some modifications (Peng et al. 2013). In brief, $1 \mathrm{ml}$ of overnight cultivated cultures were centrifuged at $13,000 \times \mathrm{g}$. at $4{ }^{\circ} \mathrm{C}$, the pellet was dissolved in $100 \mu \mathrm{l}$ of sterilized $\mathrm{dd}_{2} \mathrm{O}$, followed by vigorous homogenization by vortexing for $30 \mathrm{~s}$. The suspensions were incubated at $100{ }^{\circ} \mathrm{C}$ in a boiling water-bath for $15 \mathrm{~min}$ and immediately frozen at $0^{\circ} \mathrm{C}$ on ice. Subsequently, the suspensions were centrifuged at $13,000 \times \mathrm{g}$. at $4{ }^{\circ} \mathrm{C}$ for $15 \mathrm{~min}$. The supernatants were transferred to a clean $1.5 \mathrm{ml}$ tube and stored at $-20^{\circ} \mathrm{C}$ until PCR analysis.

\section{PCR amplification:}

In this study four types of pathogens were screened; Escherichia coli 0157:H7 as previously described (Holland et al. 2000); Salmonella 
enterica serovar Typhimurium as previously described (Park et al. 2009); Staphylococcus aureus as previously described (Wu et al. 2012); and Listeria monocytogenes as previously

Table 2) to detect the presence of each separated pathogenic strain.

The polymerase chain reaction was carried out in a cycler Sensoquest Gradient (Germany). The reaction was conducted in a final volume of $25 \mu \mathrm{l}$ containing $1 \times$ concentrated PCR buffer (containing 20mM Tris- $\mathrm{HCl}, \mathrm{pH} 8.4,1.5 \mathrm{mM} \mathrm{MgCl}$, and 50mM $\mathrm{KCl}), 100 \mathrm{nM}$ primers, 0.2mM dNTP mix, $1 \mathrm{U}$ Taq polymerase (Thermo Scientific, Fisher Scientific USA) and $3 \mu$ of DNA solution. Negative and positive controls were included in all experiments. described (Gouws and Liedemann 2005). All the one hundred and eight different milk and soft cheese samples were PCR screened with specific pair of primers presented in (

The optimized temperature and time profile of the PCR reaction was as follows: Initial denaturation: $94^{\circ} \mathrm{C}, 5 \mathrm{~min} ; 30$ cycles with the following step cycle profile: denaturation $94^{\circ} \mathrm{C}, 30 \mathrm{~s}$; annealing (54$68^{\circ} \mathrm{C}$ ), $30 \mathrm{~s}$; extension $72^{\circ} \mathrm{C}, 1 \mathrm{~min}$; final extension $72^{\circ} \mathrm{C}, 5 \mathrm{~min}$.

PCR samples were separated by electrophoresis in $1 \%$ agarose gel in TAE buffer $1 \times$ concentrated and stained with Ethidium Bromide $(0.5 \mu \mathrm{g} / \mathrm{ml})$. The PCR samples were calibrated using Smart Ladder (Eurogentec) with DNA fragments ranging between $200 \mathrm{bp}$ and 10,000 bp to determine the molecular weights of the amplicons. Gels were visualized on a Transilluminator (Ultra-Violet Product, Upland, CA, USA,) and photographed using an Orange filtered Olympus digital camera (Olympus model No. C-7070, wide zoom, Japan).

Table 2. The primer sequences and codes which used for detecting of pathogenic bacteria in raw milk and soft cheese manufactured from raw and pasteurized milk under (ISS) and (TS) during May 2013 to April 2014 in Merida, Yucatan, Mexico.

\begin{tabular}{|c|c|c|c|c|c|}
\hline Strain & Primer & Primer sequence $\left(5^{\prime} \rightarrow 3^{\prime}\right)$ & $\mathrm{Tm}$ & $\begin{array}{l}\text { Size } \\
\text { (bp) }\end{array}$ & Reference \\
\hline \multirow{2}{*}{ S. aureus } & St.a-Fw & AACTCTGTTATTAGGGAAGAACA & 55.3 & \multirow{2}{*}{756} & (Wu et al. \\
\hline & St.a-Rv & CCACCTTCCTCCCCGTTGTCACC & 67.8 & & 2012) \\
\hline \multirow{2}{*}{ S. Typhimurium } & Sa.t-Fw & AACAACGGCTCCGGTAATGAGATTG & 63.0 & \multirow{2}{*}{310} & (Park et al. \\
\hline & Sa.t-Rv & ATGACAAACTCTTGATTCTGAAGATCG & 60.4 & & 2009) \\
\hline \multirow{2}{*}{ E.coli 0157:H7 } & Ec-Fw & ACACTGGATGATCTAGTGG & 54.5 & \multirow{2}{*}{614} & (Holland et \\
\hline & Ec-Rv & CTGAATCCCCCTCCATTATG & 57.3 & & al. 2000) \\
\hline \multirow{2}{*}{$\begin{array}{l}\text { L. } \\
\text { monocytogenes }\end{array}$} & $\mathrm{Lm}-\mathrm{Fw}$ & CATTAGTGGAAAGATGGAATG & 54.0 & & (Gouws anc \\
\hline & $\mathrm{Lm}-\mathrm{Rv}$ & GTATCCTCCAGAGTGATCGA & 57.3 & 730 & $\begin{array}{c}\text { Liedemann } \\
\text { 2005) }\end{array}$ \\
\hline
\end{tabular}

Special volume for the first International Conference of Genetic Engineering and Biotechnology, Sharm el Shiekh, Egypt. 26-29 April, 2016 


\section{RESULTS AND DISCUSSION}

Data concerning the presence of bacterial species like; Escherichia coli 0157:H7, Salmonella enterica serovar Typhimurium, Staphylococcus aureus, and Listeria monocytogenes in soft cheese are scarcely available (Torres-Llanez et al. 2006; Renye et al. 2008; Omiccioli et al. 2009).

The obtained results indicated that, all of the one hundred and eight samples were negative to; Escherichia coli 0157:H7, Salmonella enterica serovar Typhimurium, and Listeria monocytogenes. The results in agreement with those found by EC (2004a; 2004b). While, for Staphylococcus aureus screening, 6 out of 108 examined samples were positive (5.56 \%) 3 samples of raw milk and other 3 samples of soft cheese manufactured from this raw milk under traditional system (Table 3\& Fig. 1).

Interestingly, all of the contaminated raw milk and soft cheese manufactured from this raw milk samples by Staphylococcus aureus were detected only in the traditional system, while it was not detected in the rest of raw milk and soft cheese samples under intensive silvopastoral system in both FMVZ and Kampepen farms (Table 3\& Fig. 1).

On the other hand, no detection of pathogenic bacteria was found in all soft cheese samples manufactured from pasteurized milk under the all production systems, these result in agreement with (Silvestre et al. 2008; Elizondo-Salazar et al. 2010; Silva et al. 2010; Van Gysel et al. 2012). In this regard, raw milk and its products are considered a big reason of food risk because they are an ideal medium for bacterial growth. In addition, Goto et al. (2007) found that
Pasteurization affected the quantity of DNA of Staphylococcus aureus found in milk when tes

by Real-Time PCR. The results presented in (Table 3) indicated that the Staphylococcus aureus which detected in soft cheese manufactured from raw milk proved the elimination role of pasteurization for all Staphylococcus aureus pathogens in soft cheese manufactured from pasteurized milk.

Soft cheeses manufactured from raw milk are highly susceptible to contain the same pathogens which found in raw milk. On the other hand, some other factors capable of eliminating pathogenic bacteria in soft cheese manufactured from raw milk, i.e., ripening of cheese in a period not less than few weeks or months which reduce cheese $\mathrm{pH}$ and eliminate any pathogenic bacteria in soft cheese manufactured from raw milk (Millet et al. 2006).

As it known that, Staphylococcus aureus is the most dangerous foodborne disease in terms of human health and it must not be found in dairy products (EC 2004a; 2004b). It is clear that raw milk and soft cheese manufactured from raw milk contains Staphylococcus aureus only during three sequential months (Table 3) from Feb. to Apr. 2014 , it might be due to the probability of infected cows with mastitis in one or more of the selected cows in this study. In agreement with the finding of Hebert et al. (2000); Barkema et al. (2006) whom stated that the infection with mastitis is common in cows. Staphylococcus aureus may occur in the milk of cows with clinical or subclinical mastitis or as the result of contamination by handlers (Hudson 2010). Therefore, more 
attention must be given to animal health for producing safety dairy products. Additionally, more attention must be given to the hygiene of workers in dairy plants.

Table 3. PCR detection of Staphylococcus aureus in raw milk and soft cheese manufactured from raw and pasteurized milk under (ISS) and (TS) during May 2013 to April 2014 in Merida, Yucatan, Mexico.

\begin{tabular}{|c|c|c|c|c|c|c|c|c|c|}
\hline \multirow{2}{*}{$\begin{array}{c}\begin{array}{c}\text { production } \\
\text { systems }\end{array} \\
\text { Samples }\end{array}$} & \multicolumn{3}{|c|}{$\begin{array}{c}\text { Traditional system } \\
\text { (FMVZ/UADY) }\end{array}$} & \multicolumn{3}{|c|}{$\begin{array}{c}\text { Intensive silvopastoral } \\
\text { system } \\
\text { (FMVZ/UADY) }\end{array}$} & \multicolumn{3}{|c|}{$\begin{array}{c}\text { Intensive silvopastoral } \\
\text { system } \\
\text { (Kampepen) }\end{array}$} \\
\hline & 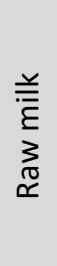 & 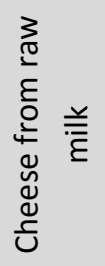 & 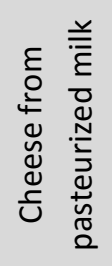 & 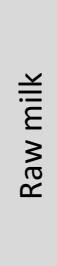 & 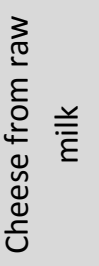 & 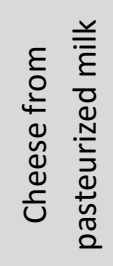 & 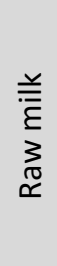 & 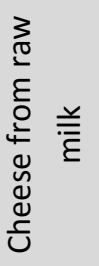 & 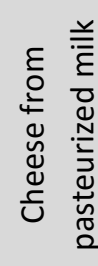 \\
\hline May 2013 & - & - & - & - & - & - & - & - & - \\
\hline Jun. 2013 & - & - & - & - & - & - & - & - & - \\
\hline Jul. 2013 & - & - & - & - & - & - & - & - & - \\
\hline Aug. 2013 & - & - & - & - & - & - & - & - & - \\
\hline Sept. 2013 & - & - & - & - & - & - & - & - & - \\
\hline Oct. 2013 & - & - & - & - & - & - & - & - & - \\
\hline Nov. 2013 & - & - & - & - & - & - & - & - & - \\
\hline Dec. 2013 & - & - & - & - & - & - & - & - & - \\
\hline Jan. 2014 & - & - & - & - & - & - & - & - & - \\
\hline Feb. 2014 & + & + & - & - & - & - & - & - & - \\
\hline Mar. 2014 & + & + & - & - & - & - & - & - & - \\
\hline Apr. 2014 & + & + & - & - & - & - & - & - & - \\
\hline
\end{tabular}

FMVZ/UADY: Farm of Faculty of Veterinary Medicine and Animal Science, Autonomous University of +: Contaminated samples. $\quad-:$ Non contaminated samples.

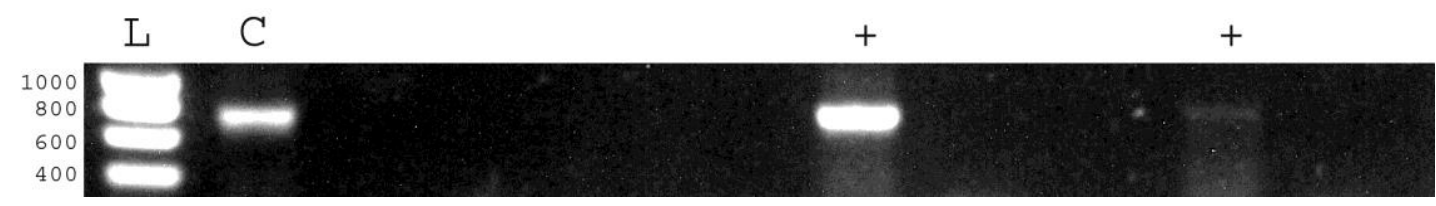

Fig. 1. Agarose electrophoresis separation of one of the agarose gels used in the detection of Staphylococcus aureus, which is presented. Lane L: Molecular weight Ladder. Lane C: Positive control. Empty lanes mean that these samples were not contaminated with Staphylococcus aureus, while lanes with bands (+) mean that these samples are contaminated with Staphylococcus aureus. 
PCR detection showed that all samples were negative for almost tested pathogens (Escherichia coli 0157:H7, Salmonella enterica serovar Typhimurium and Listeria monocytogenes) except six samples (5.56\%); 3 samples of raw milk and other 3 samples of soft cheese manufactured from this raw milk under traditional system which were positive for Staphylococcus aureus. Once milk has been contaminated with Staphylococcus aureus, they can subsequently grow in dairy products manufactured from this contaminated milk. The milk pasteurization is recommended with animal health care and hygiene of workers in dairy plants. The results obtained for detected the pathogenic bacteria in the present study were compared with European Commission (EC) and it clearly indicate that the consumption of raw milk and soft cheese manufactured from raw milk under traditional system in (FMVZ/UADY) farm is not recommended due to the presence of Staphylococcus aureus.

\section{REFERENCES}

Aldrete-Tapia A, Escobar-Ramirez MC, Tamplin ML and Hernandez-Iturriaga M (2014) Highthroughput sequencing of microbial communities in Poro cheese, an artisanal Mexican cheese. Food Microbiol 44 136-141.

Amagliani G, Omiccioli E, Campo A, Bruce I, Brandi $G$ and Magnani M (2006) Development of a magnetic capture hybridization-PCR assay for Listeria monocytogenes direct detection in milk samples. Journal of applied microbiology 100 375-383.

Barkema HW, Schukken YH and Zadoks RN (2006) Invited Review: The role of cow, pathogen, and treatment systemn in the therapeutic success of bovine Staphylococcus aureus mastitis. J Dairy Sci 89 1877-1895.
Barros-Rodríguez M, Solorio-Sánchez J, Ku-Vera J, Ayala-Burgos A, Sandoval-Castro C and SolísPérez G (2012) Productive performance and urinary excretion of mimosine metabolites by hair sheep grazing in a silvopastoral system with high densities of Leucaena leucocephala. Tropical animal health and production 44 1873-1878.

Bergdoll MS (1997) Toxic shock syndrome. Rev J Venom Anim Toxins 1 6-21.

Chang CT, Yuo CY, Shen HC, Li AM, Chen CY, Chou $\mathrm{JI}$ and Huang SP (1999) Recovery of Salmonella by using selenite brilliant green sulfa enrichment broth. Journal of clinical microbiology 37 4120-4123.

Elizondo-Salazar JA, Jones $\mathrm{CM}$ and Heinrichs $\mathrm{AJ}$ (2010) Evaluation of calf milk pasteurization systems on 6 Pennsylvania dairy farms. J Dairy Sci 93 5509-5513.

European Commission (2004a) Regulation (EC) No. $852 / 2004$ of the European Parliament and of the Council of 29 April 2004 on hygiene of foodstuffs. Official Journal of the European Community L139 1-54.

European Commission (2004b) Regulation (EC) No. $853 / 2004$ of the European Parliament and of the Council of 29 April 2004 laying down specific hygiene rules for food of animal origin. Official Journal of the European Community L139 55-205.

Fox PF, mcsweeney PL, Cogan TM and Guinee TP (2004) Cheese: Chemistry, Physics and Microbiology: General Aspects. 3 ed. Academic Press

Goto M, Takahashi H, Segawa Y, Hayashidani H, Takatori $K$ and Hara-Kudo Y (2007) Real-time PCR method for quantification of 
Staphylococcus aureus in milk. J Food Prot 70 90-96.

Gould LH, Mungai E and Behravesh CB (2014) Outbreaks attributed to cheese: differences between outbreaks caused by unpasteurized and pasteurized dairy products, United States, 1998-2011. Foodborne Pathog Dis 11 545-551.

Gouws PA and Liedemann I (2005) Evaluation of diagnostic PCR for the detection of Listeria monocytogenes in food products. Fand Technology and Biotechnology 43 201-2C 114

Hebert A, Sayasith K, Senechal S, Dubreuil P and Lagace J (2000) Demonstration of intracellular Staphylococcus aureus in bovine mastitis alveolar cells and macrophages isolated from naturally infected cow milk. FEMS Microbiol Lett 193 57-62.

Holland J, Louie L, Simor A and Louie M (2000) PCR detection of Escherichia coli 0157: H7 directly from stools: evaluation of commercial extraction methods for purifying fecal DNA. Journal of clinical microbiology 38 4108-4113.

Hudson JA (2010) Evaluation of methods for detection of coagulase positive staphylococcus and staphylococcal toxin in milk and cheese. Prepared for New Zealand Food Safety Authority under project MFS/09/09 - Evaluation of methods for detection of coagulase positive Staphylococcus aureus and staphylococcal toxin in milk and cheese, as part of overall contract for scientific services pp 1-30.

Leuschner RG and Boughtflower MP (2002) Laboratory-scale preparation of soft cheese artificially contaminated with low levels of Escherichia coli 0157, Listeria monocytogenes, and Salmonella enterica serovars Typhimurium, Enteritidis, and Dublin. J Food Prot 65 508-514.

Lye Y, Afsah-Hejri L, Chang W, Loo Y, Puspanadan S, Kuan C, Goh S, Shahril N, Rukayadi Y and Khatib A (2013) Risk of Escherichia coli 0157: $\mathrm{H} 7$ transmission linked to the consumption of raw milk. International Food Research Journal 20 1001-1005.

Millet L, Saubusse M, Didienne R, Tessier $L$ and Montel MC (2006) Control of Listeria monocytogenes in raw-milk cheeses. Int J Food Microbiol 108 105-114.

Morales-Celaya M, Lobato-Calleros C, AlvarezRamirez J and Vernon-Carter E (2012) Effect of milk pasteurization and acidification method on the chemical composition and microstructure of a Mexican pasta filata cheese. LWT-Food Science and Technology 45 132-141.

Nedelkov D, Rasooly A and Nelson RW (2000) Multitoxin biosensor-mass spectrometry analysis: a new approach for rapid, realtime, sensitive analysis of staphylococcal toxins in food. Int J Food Microbiol 60 1-13.

Olson DW, Van Hekken DL, Tunick MH, Tomasula PM, Molina-Corral FJ and Gardea AA (2011) Mexican Queso Chihuahua: functional properties of aging cheese. J Dairy Sci 94 4292-4299.

Omiccioli E, Amagliani G, Brandi G, Bruce IJ and Magnani M (2009) Simultaneous direct detection of Salmonella spp., Listeria monocytogenes and Escherichia coli 0157 in milk samples by magnetic extraction and multiplex PCR. Journal of Rapid Methods \& Automation in Microbiology 17 195-213. 
Park SH, Kim HJ, Cho WH, Kim JH, Oh MH, Kim SH, Lee BK, Ricke SC and Kim HY (2009) Identification of Salmonella enterica subspecies I, Salmonella enterica serovars Typhimurium, Enteritidis and Typhi using multiplex PCR. FEMS microbiology letters 301 137-146.

Peng X, Yu KQ, Deng GH, Jiang YX, Wang Y, Zhang GX and Zhou HW (2013) Comparison of direct boiling method with commercial kits for extracting fecal microbiome DNA by Illumina sequencing of $16 \mathrm{~S}$ rrna tags. Journal of microbiological methods 95 455-462.

Pereira-Suarez AL, Estrada-Chavez Y, ZunigaEstrada A, Lopez-Rincon G, Hernandez DU, Padilla-Ramirez FJ and Estrada-Chavez C (2014) Detection of Mycobacterium tuberculosis complex by PCR in fresh cheese from local markets in Hidalgo, Mexico. J Food Prot 77 849-852.

Rahimi E and Alian F (2013) Presence of enterotoxigenic Staphylococcus aureus in cow, camel, sheep, goat, and buffalo bulk tank milk. Veterinarski Arhiv 83 23-30.

Renye J, Somkuti G, Vallejo-Cordoba B, Van Hekken D and Gonzalez-Cordova A (2008) Characterization of the microflora isolated from queso fresco made from raw and pasteurized milk. Journal of Food Safety 28 59-75.

Renye JAJr, Somkuti GA, Van Hekken DL and Guerrero Prieto VM (2011) Short communication: characterization of microflora in Mexican Chihuahua cheese. J Dairy Sci 94 3311-3315.

Silva R, Cruz AG, Faria JA, Moura MM, Carvalho LM, Water EH and Sant'Ana AS (2010) Pasteurized milk: efficiency of pasteurization and its microbiological conditions in Brazil. Foodborne Pathog Dis 7 217-219.

Silvestre D, Ruiz P, Martinez-Costa C, Plaza A and Lopez MC (2008) Effect of pasteurization on the bactericidal capacity of human milk. J Hum Lact 24 371-376.

Solano-López C and Hernández-Sánchez H (2000) Behaviour of Listeria monocytogenes during the manufacture and ripening of Manchego and Chihuahua Mexican cheeses. International journal of food microbiology 62 149-153.

Torres-Llanez M, Vallejo-Cordoba B, Díaz-Cinco M, Mazorra-Manzano M and González-Córdova A (2006) Characterization of the natural microflora of artisanal Mexican Fresco cheese. Food control 17 683-690.

U.S. Food and Drug Administration (2001) Foodborne pathogenic microorganisms and natural toxins. Available at:

http://www.fda.gov/Food/FoodSafety/Foodborn elllnes/FoodbornelllnessFoodborne PathogensNaturalToxins/BadBugBook/ucm0 70015.htm. Accessed 2 October 2009.

Van Gysel M, Cossey V, Fieuws S and Schuermans A (2012) Impact of pasteurization on the antibacterial properties of human milk. Eur $J$ Pediatr 171 1231-1237.

Wu Q, Li Y, Hu H, Wang M, Wu Z and Xu W (2012) Rapid Identification of Staphylococcus aureus: FISH Versus PCR Methods. Lab Medicine 43 276-280. 